\title{
SAMUEL BECKETT
}

\author{
Tre dialoger
}

Tal coat

B.- Et totalobjekt med manglende dele i stedet for et delobjekt. Det er et gradsspørgsmål.

D.- Det er mere. Det er også en forkastelse af diskretionens tyranni. Verden anskuet som en strøm af bevægelser, en del af den levende tid, arbejdets, skabelsens, frigørelsens, maleriets og malerens tid. Det flygtige øjebliks sansning givet tilbage og fremholdt i det kontinuum, som giver det næring.

B.- I hvert fald et tilløb til et mere dækkende udtryk for den naturlige oplevelse, sådan som den åbenbares for den årvågne coenæsthesis. Hvad enten den opnås gennem underkastelse eller beherskelse, er resultatet en forøget naturlighed.

D.- Men det som denne maler afdækker, arrangerer og formidler findes ikke i naturen. Hvad er forholdet mellem et af disse malerier og et landskab set $i$ en bestemt alder, på en bestemt årstid, på et bestemt tidspunkt? Er vi ikke på et ganske andet plan?

B.- Ved naturen forstår jeg her, som den mest naive realist, en enhed af beskueren og det beskuede, ikke et datum eller en oplevelse. Jeg vil bare sige, at tendensen og bestræbelsen i denne malerkunst dybest set er den samme som i tidligere malerkunst, bortset fra at den kræver mere plads til et kompromis.

D.- Du overser den meget store forskel på perceptionens betydning for henholdsvis Tal Coat og flertallet af hans forgængere, der selv når de oplever som kunstnere, gør det med en utilitaristisk servilitet som i en trafikprop og forbedrer resultatet med en klat euklidisk geometri. Tal Coats globale perception er uhildet, hverken engageret i sandhed eller skønhed, naturens dobbelte tyranni. Jeg kan godt se et kompromis i fortidens malerkunst, men ikke det som du beklager hos Matisse i en bestemt periode og hos Tal Coat i dag.

B.- Jeg beklager ikke noget. Jeg er enig i, at både Matisse i den pågældende periode og Tal Coats franciskanske orgier har stor værdi, men det er en værdi som er beslægtet med allerede akkumulerede værdier. Hvad vi bør fæste os ved hos de italienske malere er ikke, at de betragtede verden med en bygherres øjne, som et rent og skært middel, men at de aldrig fjernede sig fra det muliges felt, uanset hvor meget de udvidede det. Det eneste, der er ændret af revolutionære som Matisse og Tal Coat, er en vis orden på det muliges plan.

D.- Hvilket andet plan findes for den skabende? 
B.- Rent logisk intet. Men jeg taler om en kunst, der vender sig bort fra det i lede, som er træt af dets usle bedrifter, træt af at foregive at kunne, at være $i$ stand til at gøre det sædvanlige en lille smule bedre, at gå en lille smule længere ad en kedsommelig vej.

D.- Og som i stedet foretrækker hvad?

B.- At udtrykke, at der ikke er noget at udtrykke, intet at udtrykke med, intet at udtrykke fra, ingen kraft til at udtrykke, intet ønske om at udtrykke, men stadig forpligtelsen til at udtrykke.

D.- Det er en voldsom, ekstremt personlig opfattelse, som ikke gør os spor klogere på Tal Coat.

B.-

D.- Måske er det nok for i dag.

II

Masson

B.- På sporet efter problemet snarere end knuget af det. Rastløsheden hos den, der savner modstand.

D.- Det er måske derfor, han så ofte nu for tiden taler om at male tomheden i "frygt og bæven". En overgang beskæftigede han sig med at skabe en mytologi, derefter med mennesket, ikke kun i universet, men i samfundet; og nu ... med "den indre tomhed, ifølge kinesisk æstetik den første betingelse for at kunne male”. Noget tyder på, at Masson mere end nogen anden nulevende maler lider under behovet for at finde hvile, dvs. etablere de faktiske data i det problem, der skal løses, og omsider finde Problemet.

B.- Jeg er ikke bekendt med de problemer, han har stillet sig selv i fortiden, og som nu har mistet deres legitimitet for ham, enten fordi de kan løses eller af andre grunde, men jeg aner alligevel deres tilstedeværelse lige bag disse billeder som skjult bestyrtelse, som ar efter en teknisk færdighed, der må være særdeles ubehagelig for ham. To gamle onder, som bør behandles hver for sig - ønsket om at vide, hvad man kan og bør gøre, og ønsket om at være i stand til at gøre det.

D.- Men Massons erklærede hensigt er at reducere disse onder, som du kalder dem, til ingenting. Han håber på at befri sig for slaveriet i forholdet til rummet, så hans øjne kan "boltre sig mellem fokusløse felter, der myldrer af uophørlig tilblivelse". Samtidig kræver han at det "dampformige" skal rehabiliteres. Det kan forekomme ejendommeligt hos en mand, der af temperament synes mere egnet til ild end til damp. Du vil naturligvis sige, at det er det samme som før, den samme søgen efter hjælp udefra. Objektet forbliver altafgørende, hvad enten det er gennemsigtigt eller det modsatte. Men hvordan kan man forvente, at Masson skal male tomheden? B.- Det kan man heller ikke. Hvad nytter det at skifte fra det ene uholdbare standpunkt til det andet eller altid at søge berettigelse på det samme plan? Han er en kunstner, der synes at være bogstavelig talt spiddet på det kunstneriske udtryks rasende dilemma. Men han bliver ved med at vride sig. Den tomhed, han taler om, er måske kun udslettelsen af en uudholdelig gestalt, der netop er uudholdelig fordi den hverken lader sig besnære eller bestorme. Hvis denne angst og hjælpeløshed aldrig 
udtrykkes som det den er i sin iboende karakter og for sin egen skyld, selv om den måske en sjælden gang erkendes som et krydderi på den "præstation”, den risikerer at undergrave, er årsagen utvivlsomt blandt andet, at den i kraft af sin beskaffenhed er umulig at udtrykke. Også her en særdeles logisk anskkuelse. Men den må ikke forveksles med tomhed.

D.- Masson taler meget om gennemsigtighed - “åbninger, cirkulationer, kommunikationer, ukendte former for indtrængen” - hvor han kan boltre sig sorgløst og i frihed. Uden at give afkald på objekterne, de være sig frastødende eller tiltalende, som er vores daglige brød og vin og fængsel, forsøger han at bryde igennem deres skillevægge til den kontinuitet $\mathrm{i}$ eksistensen, der mangler i den almindelige livserfaring. I denne henseende nærmer han sig Matisse (i den første periode, det siger sig selv) og Tal Coat, men med den væsentlige forskel, at han skal slås med sin tekniske dygtighed, der har samme fylde, præcision, tæthed og balance som i den klassiske tradition. Eller måske skulle jeg hellere sige dens ånd, for han har lagt stor teknisk variation for dage, når det har været nødvendigt.

B.- Det du siger, illustrerer denne kunstners dramatiske situation. Jeg vil tilføje, at han sætter stor pris på lethd og frihed. Stjernerne er uden tvivl ypperlige, som Freud sagde, da han havde læst Kants kosmologiske bevis på Guds eksistens. Når han har den slags interesser, forekommer det mig umuligt, at han vil skabe noget der er anderledes end det som de bedste, deriblandt han selv, allerede har skabt. Det er måske uforskammet at antyde, at han skulle ønske det. I hans uhyre intelligente bemærkninger om rummet fornemmer man den samme besiddelsestrang som i Leonardos dagbøger, når han taler om disfazione vel vidende, at ikke et eneste fragment vil gå tabt for ham. Så du må undskylde, hvis jeg ligesom da vi talte om den meget anderledes Tal Coat falder tilbage på min drøm om en kunst, der ikke beklager sin egen armod og er for stolt til at give og modtage på en farceagtig måde. D.- Masson siger selv, at den vestlige verdens perspektiv kun er et antal fælder til at indfange objekter med, og at det ikke interesserer ham at besidde dem. Han han roser Bonnard, fordi han i sine sidste værker "bevægede sig ud over enhver form for besiddende rum, fjernt fra opmåling og grænser, til et punkt hvor al besiddelse er opløst". Jeg er enig i, at der er langt fra Bonnard til den forarmede malerkunst, der er "autentisk ufrugtbar og ude af stand til at frembringe et billede", som du tilstræber, og som måske også Masson ubevidst arbejder hen imod. Men skal vi virkelig beklage en malerkunst, der beskæftiger sig med "forårets frodighed, dets livsbekræftende begær, dets flygtige, men evigt tilbagevendende herlighed", ikke for at udnytte det eller nyde det, men for at verdens herlighed kan videreføres? Skal vi virkelig beklage en malerkunst, der kalder på os for at minde os om en tid, der varer ved og gør fyldest, når vi står omgivet af tidens ting, der forsvinder og jager os videre? B.- (Går grædende.)

B.- Franskmand, fyr løs. 
D.- Da du talte om Tal Coat og Masson, skitserede du en kunst af en anden art, ikke kun forskellig fra deres, men fra al kunst hidtil. Har jeg ret $i$, at det var Bram van Velde, du tænkte på, da du fremsatte denne lige lovlig flotte generalisering?

B.- Ja. Jeg tror, han er den første der har affundet sig med en vis situation og er gået med til en bestemt handling.

D.- Må jeg bede dig om en gang til og så enkelt som muligt at beskrive hans situation og handling?

B.- Situationen vedrører den, som er hjælpeløs, ikke kan handle, i givet fald ikke male, men er forpligtet til at male. Handlingen vedrører den, der er hjælpeløs og ikke kan handle, men handler, i givet fald maler, fordi han er forpligtet til at male.

D.- Hvorfor er han forpligtet til at male?

B.- Det ved jeg ikke.

D.- Hvorfor kan han ikke male?

B.- Fordi der ikke er noget at male og ikke noget at male med.

D.- Og resultatet, siger du, er en ny slags kunst?

B.- Når vi taler om såkaldt store kunstnere, kan jeg ikke komme i tanker om en eneste, der ikke $\mathrm{i}$ altovervejende grad har været optaget af sine udtryksmuligheder, af sit mediums muligheder, af menneskets muligheder. Til grund for al malerkunst ligger den antagelse, at skaberens domæne er det muliges domæne. Meget at udtrykke, lidt at udtrykke, evnen til at udtrykke meget, evnen til at udtrykke lidt, blandes i den fælles iver efter at udtrykke så meget som muligt eller at udtrykke det så sandt som muligt eller så smukt som muligt, efter bedste evne. Hvad -

D.- Lige et øjeblik. Siger du, at van Veldes malerier savner udtryk?

B.- (Fjorten dage senere.) Ja.

D.- Du er vel klar over, at det er en absurd påstand?

B.- Det håber jeg.

D.- Det du siger kan sammenfattes som følger: den udtryksform, der kaldes malerkunst - eftersom vi uvist af hvilken grund er nødt til at tale om malerkunst - har måttet vente på van Velde for at blive fri for den vildfarelse, som den så længe og tappert har levet med, nemlig at dens funktion var at udtrykke noget ved hjælp af maling.

B.- Også andre har ment, at kunst ikke nødvendigvis er udtryk. Men de mangfoldige forsøg på at gøre malerkunsten uafhængig af dens udgangspunkt har kun bevirket, at den har fảet et endnu større repertoire. Jeg mener, at van Velde er den første kunstner, hvis kunst er berøvet - eller er fri for, om man vil - enhver form for udgangspunkt, det være sig ideelt eller materielt, og den første kunstner, hvis hænder ikke har været bundet af visheden om, at udtrykket er en umulig handling.

D.- Men selv om man går ind for denne fantastiske teori, kunne man så ikke tænke sig, at udgangspunktet for hans malerkunst er hans problematiske situation, og at den netop er udtryk for umuligheden af at udtrykke sig?

B.- En mere sindrig måde at føre ham velbeholden tilbage til Skt. Lukas’ barm på skal man lede længe efter. Men lad os for en gangs skyld være tåbelige nok til ikke at stikke halen mellem benene. Alle har hidtil klogeligt stukket halen mellem benene ved udsigten til den endelige armod og er vendt tilbage til den almindelige fattigdom, som giver en subsistensløs dydig mor lov til at stjæle muggent brød til sine 
sultne unger. Der er mere end en gradsforskel på at være i bekneb, i bekneb for verden, $i$ bekneb for sig selv, og så at mangle den slags fødemidler. Det ene er en problematisk situation, det andet er det ikke.

D.- Men du har allerede kaldt van Veldes situation problematisk.

B.- Det skulle jeg ikke have gjort.

D.- Du foretrækker den renere opfattelse, at vi her omsider har en maler, der ikke maler, ikke foregiver at male. Hør nu, min kære ven, sig nu noget sammenhængende, og gå så din vej.

B.- Kan jeg ikke bare nøjes med at gå min vej?

D.- Nej. Nu er du begyndt. Gør det færdigt. Begynd forfra og bliv ved, indtil du er færdig. Og gå så din vej. Prøv at huske på, at det foreliggende emne ikke er dig selv og heller ikke sufien al-Haqq, men en bestemt hollænder ved navn van Velde, der hidtil fejlagtigt har været omtalte som artiste peintre.

B.- Hvad nu, hvis jeg begynder med at sige, hvad jeg gerne forestiller mig, at han er og gør, og derefter siger, at det er højst sandsynligt, at han er og gør noget ganske andet? Ville det ikke være en glimrende vej ud af vors trænglser? Han er glad, du er glad, jeg er glad, vi er alle tre tindrende glade.

D.- Gør, som du vil. Men få det overstået.

B.- Det som jeg forgæves prøver at sige, kan forgæves siges på mange forskellige måder. Som du ved, har jeg både offentligt og privat, hårdt presset, på grund af skiftende mod eller svigtende åndsevner, eksperimenteret med to-tre hundrede sådanne måder. Den hjertegribende antitese mellem besiddelse og fattigdom var måske ikke den mest kedelige. Men vi er allerede ved at blive trætte af den, ikke sandt? Erkendelsen af, at kunst altid har været borgerlig, er i sidste ende uden større interesse, selv om den måske kan lindre vores smerte ved sociale fremskridt. Analysen af forholdet mellem kunstneren og hans udgangspunkt, et forhold der altid anses for at være uomgængeligt nødvendigt, lader heller ikke til at have været særlig produktiv, måske fordi det er faret vild i vidtløftigheder om udgangspunktets art. Det er indlysende, at hvis en kunstner ser det som et kald at udtrykke sig, er alt dømt til at blive udgangspunkt, også udgangspunktet for dets egen skyld, som det åbenbart $i$ et vist omfang er tilfældet for Massons vedkommende eller for den åndelige Kandinsky, hvor det bliver til kyske eksperimenter. Men hvis udgangspunktet er ubestemmeligt, er kunstneren det endnu mere i kraft af sine skiftende holdninger og arbejdsmåder. Indvendingerne mod denne dualistiske opfattelse af den skabende proces er ikke overbevisende. To forhold etableres, om end på et spinkelt grundlag: næringen - fra frugter på fade til dårlig matematik og selvmedlidenhed - og dens formidling. Det eneste der bør interessere os er den stærke og tiltagende angst ved det kunstneriske projekt, der er omgivet af ugyldighedens stadig mørkere skygger, af utilstrækkeligheden, af en tilværelse præget af alt det som det udelukker, alt det som det gør blind for. Maleriets historie, for nu at sige det en gang til, er historien om forskellige forsøg på at overvinde denne misere ved hjælp af et mere autentisk, et mere rummeligt, et mindre ekskluderende forhold mellem gengiver og gengivet, en slags tropisme mod lyset om hvis nærmere karakter der stadig disputeres, og med en slags pythagoræisk rædsel, som om pi var en irrationel krænkelse både af guddommen og hans discipel. Da jeg sidder på anklagebænken, må mit forsvar være, at van Velde er den 
første, der har afstået fra denne æstetiserede automatisme, den første der har erkendt, at man som kunstner lider nederlag, som få andre har mod til at gøre det, at nederlaget er kunstnerens verden, og at man deserterer, når man viger tilbage for det, svigter kunst og håndværk, en ordentlig husførelse, et anstændigt liv. Nej, nej, lad mig nu ånde ud. Alt hvad der nu kræves for at gøre en passende ende også på dette frygtelige spørgsmål er at gøre denne underkastelse for, denne indrømmelse til, denne troskab mod nederlaget til et nyt udgangspunkt, et nyt vilkår, og at gøre den handling, han udfører, skønt ude af stand til at handle, men forpligtet til det, til et udtryk, om så kun et udtryk for sig selv, for sin umulighed, for sin forpligtelse. Jeg ved, at min manglende evne til at gøre det måske uforvarende anbringer mig i en vistnok stadig såkaldt lidet misundelsesværdig situation, som psykiatere er fortrolig med. For hvad er det for et farvet plan, der aldrig har været der før. Jeg ved ikke, hvad det er, eftersom jeg aldrig før har set noget lignende. Det synes ikke at have noget med kunst at gøre, hvis mine minder om kunst ellers er pålidelige. (Gør sig klar til at gå.)

D.- Glemmer du ikke noget?

B.- Det må da være nok?

D.- Jeg forstod, at dit nummer skulle have to dele. Først skulle du sige, hvad du - hm - havde tænkt. Jeg er villig til at acceptere, at du allerede har gjort det. Og dernæst

B.- (Husker det, varmt) Ja, ja, jeg tager fejl, jeg tager fejl.

På dansk ved Claus Bech 
